c) (7) (8)

\title{
O Ginásio Anglo-Mineiro e as representações de Pedro Nava sobre o trabalho docente
}

\author{
Márcio José Pereira de Camargo \\ Universidade de Sorocaba - UNISO, Sorocaba/SP, Brasil \\ Wilson Sandano \\ Universidade de Sorocaba - UNISO, Sorocaba/SP, Brasil
}

\section{RESUMO}

Neste artigo, discutem-se as representações que o escritor Pedro da Silva Nava (1903-1984) constrói sobre a escola, particularmente no que tange ao trabalho docente, tendo como objeto de estudo a obra Balão cativo: memórias/2 (1973), segundo volume da série intitulada Memórias. Com fulcro nos pressupostos da História Cultural (CHARTIER, 2002; PESAVENTO, 2014), intenta-se compreender como se constituem as representações naveanas sobre o professor, a partir das experiências vividas pelo escritor enquanto aluno interno no Ginásio Anglo-Mineiro, em Belo Horizonte, entre os anos de 1914 e 1915. O estudo interpretativo da obra, na perspectiva dos sentidos que o narrador atribui ao trabalho docente, revela um estilo próprio do escritor, do qual emana predominantemente o reconhecimento pelas contribuições da escola para seu percurso de formação.

PALAVRAS-CHAVE: Pedro Nava. Ginásio Anglo-Mineiro. Trabalho docente.

\section{GINÁSIO ANGLO-MINEIRO PRIMARY SCHOOL AND THE REPRESENTATIONS OF PEDRO NAVA ABOUT TEACHING WORK}

\begin{abstract}
This article discusses the representations that the writer Pedro da Silva Nava (1903-1984) constructs about the school, particularly regarding teaching work, focusing on as study object the work Balão cativo: memórias/2 (1973), second volume of his Memórias. Grounded in the assumptions of the Cultural History (CHARTIER, 2002; PESAVENTO, 2014), this study aims to understand how the representations of Nava about the teacher are constituted, from the experiences lived by the writer as an internal student at the Ginásio Anglo-Mineiro Primary School, in Belo Horizonte, between 1914 and 1915. The interpretative study of the work, from the perspective the meanings that the narrator attributes to the teaching work, reveals a personal style of the writer, from which the recognition for the contributions of the school to his formative path predominantly emanates.
\end{abstract}

KEY WORDS: Pedro Nava. Ginásio Anglo-Mineiro Primary School. Teaching work. 


\section{EL GINÁSIO ANGLO-MINEIRO Y LAS REPRESENTACIONES DE PEDRO NAVA SOBRE EL TRABAJO DOCENTE}

\section{RESUMEN}

En este artículo, se discuten las representaciones que el escritor Pedro da Silva Nava (19031984) construye sobre la escuela, particularmente en lo que respecta al trabajo docente, teniendo como objeto de estudio la obra Balão cativo: memórias/2 (1973), segundo volumen de las Memórias. Basándose en los presupuestos de la Historia Cultural (CHARTIER, 2002; PESAVENTO, 2014), se intenta comprender como se constituyen las representaciones de Nava sobre el profesor, a partir de las experiencias vividas por el escritor como alumno interno en el Ginásio Anglo-Mineiro, en Belo Horizonte, entre 1914 y 1915. Centrada en los sentidos que el narrador atribuye al trabajo docente, la interpretación de la obra revela un estilo propio del escritor, del cual subyace el reconocimiento por las contribuciones de la escuela para su trayectoria de formación.

PALABRAS CLAVE: Pedro Nava. Ginásio Anglo-Mineiro. Trabajo docente.

\section{INTRODUÇÃO}

A reflexão proposta neste artigo é parte de uma pesquisa em andamento e busca discutir as representações da escola presentes em Balão cativo: memórias/2, de Pedro da Silva Nava (1903-1984), com ênfase em como se apresenta a figura do professor nos sentidos construídos pelo narrador para a escola e, em particular, para o trabalho docente.

Publicado em 1973, o livro corresponde ao segundo volume das Memórias $^{1}$ do médico e escritor, no qual ele rememora seus primeiros tempos escolares, passando pelo período de alfabetização em Juiz de Fora, cidade mineira onde nasceu, suas experiências como aluno interno do recém-inaugurado Ginásio Anglo-Mineiro, na capital Belo Horizonte, até seus primeiros contatos no tradicional Colégio Pedro II, localizado no Rio de Janeiro.

Com foco nas vivências de Nava no internato do Ginásio Anglo-Mineiro, durante os anos de 1914 e 1915, retratados na narrativa, este estudo sustenta-se nos pressupostos da História Cultural (CHARTIER, 2002; PESAVENTO, 2014), que propõem novos referenciais, métodos e fontes de pesquisa, entre os quais se inserem os textos literários. A investigação tem

\footnotetext{
$1 \mathrm{O}$ termo Memórias, aqui, é empregado para designar toda a série de seis livros completos, publicados pelo autor entre 1972 e 1984, acrescidos de um sétimo volume incompleto, publicado postumamente em 2006.
} 
caráter exploratório e sua abordagem é qualitativa, na medida em que centra seu interesse nos processos pelos quais se constroem sentidos para a realidade social (MINAYO, 2009).

Assim, os tópicos aqui abordados obedecem à seguinte sequência: primeiramente apresenta-se o Ginásio Anglo-Mineiro no contexto da educação no Brasil; em seguida, reconstituem-se brevemente os anos iniciais da vida de Pedro Nava, dando-se a conhecer as relações familiares que marcaram esse período, bem como as primeiras experiências escolares até o ingresso do jovem no internato, para completar os estudos primários; por fim, analisamse as representações de Nava sobre o trabalho docente no Anglo-Mineiro, discutindo-se os sentidos que o escritor atribui à figura do professor e suas contribuições para seu processo formativo.

\section{O GINÁSIO ANGLO-MINEIRO NO CONTEXTO EDUCACIONAL BRASILEIRO}

Por volta de 1912, por iniciativa de Francisco Mendes Pimentel - destacada figura pública em torno da qual orbitava a "Tradicional Família Mineira" -, representantes das elites de Belo Horizonte se reuniram com o intuito de criar na capital mineira o seu Eton, isto é, um colégio que, a exemplo do Eton College, tradicional colégio britânico de elite, representasse uma instituição moderna para nela matricularem seus filhos. Entre esses chamados "homens bons", figuravam professores, altos funcionários, homens de dinheiro, políticos, e, de modo geral, pessoas influentes na sociedade (NAVA, 1974).

Essa disposição da sociedade local encontrou, na pessoa do professor inglês Joseph Thomas Wilson Sadler, a parceria perfeita. Após desentender-se com o proprietário do Ginásio Anglo-Brasileiro, instituição localizada em São Paulo e na qual atuara como professor de conversação inglesa e vice-diretor, Sadler resolvera criar, em Belo Horizonte, um ginásio que suplantasse o rival paulistano.

Assim, como resultado dessa confluência de intenções e esforços, nascia em Belo Horizonte o Ginásio Anglo-Mineiro, cujo início das atividades letivas se deu em 1914. Dotados de prodigiosa infraestrutura, os 49.200 metros quadrados de terreno reuniam "amplas salas de aulas, espaçosas dependências, piscina, galpão de ginástica, campos de futebol, lawn-tennis, críquete e hóquei" (NAVA, 1974, p. 117), a que se podiam acrescentar os amplos vestiários e lavatórios, além de uma enfermaria especial para os meninos que adoecessem.

Ao refletir sobre o surgimento do Anglo-Mineiro, Anjos (1979, p. 72) afirma: 
Brasil. A Constituição liberal e republicana de 1891 estabeleceu a laicidade do ensino, propiciando a liberdade de crenças. Com a separação da Igreja Católica (religião oficial do Império) e do Estado, e à sombra do princípio constitucional da liberdade de pensamento, a política escolar da Igreja, até então estabelecedora de um quase exclusivo monopólio de orientação espiritual, começou a encontrar rivalidade em pontos de vistas confessionais protestantes, que tomavam vulto com a intensa imigração desenvolvida no Brasil no final do século XIX.

Sobre o caráter laico do ginásio, confirma-o a própria narrativa de Nava, ao reproduzir os anúncios que circulavam na imprensa local, nos quais, além da arrojada infraestrutura e da competência do corpo docente, exaltava-se a liberdade de culto, com a ressalva de que, tendo em vista o regime de internato, encarregava-se a diretoria de mandar acompanhar os meninos ao templo, nos domingos, para os cultos que os pais indicassem, se assim o quisessem (NAVA, 1974).

A legislação educacional daqueles primeiros tempos de República contribuiria, ainda, para a instalação e configuração do ginásio pelos ingleses por meio da desoficialização do ensino promovida pelo Decreto n. ${ }^{\circ}$ 8.659, de 5 de abril de 1911, a chamada Reforma Rivadávia Corrêa. De matriz positivista, o documento instituía o ensino livre e conferia autonomia didática e administrativa às escolas particulares.

Tinha-se, assim, a emergência de um cenário extremamente favorável à instalação de um ginásio particular que atendesse satisfatoriamente as intenções de parte da sociedade mineira, estabelecida na capital do estado: a laicidade do ensino e maior autonomia para o desenvolvimento do currículo escolar.

A tais condições, Anjos (1979) acrescenta a dependência sociocultural que ficava evidenciada em nosso sistema educacional, fator segundo o qual se aceitava acriticamente, sem a devida contextualização para a realidade nacional, a mera importação de ideais de educação europeus e de um sistema educacional que se proclamava o mais adequado para a formação de um cidadão brasileiro.

Organizado sob os regimes de externato e internato, o ginásio, a despeito de sua orientação elitista, "apresentava à sociedade da época ideias e processos didáticos renovadores, num cenário em que predominavam aulas que ainda seguiam a tradição imperial de beletrismo e austeridade" (ANJOS, 1979, p. 73). Um dos exemplos desse caráter renovador era o ensino de inglês e francês, deixando de lado o latim, língua que não podia faltar no currículo dos colégios católicos.

Ademais, as novidades trazidas pelos ingleses causavam alvoroço entre os educadores 
tradicionais, que chegavam a escandalizar-se com "aquele colégio sem latim, nenhum catecismo e excesso de esportes" (NAVA, 1974, p. 118). Neste último quesito, em particular, veja-se o relato do narrador, que o confirma enfaticamente: "Era futebol demais. E logo futebol - coisa que puxava pelos peitos, meu Deus! que era um verdadeiro despropósito..." (idem).

No mais, caracterizou-se o Anglo-Mineiro pelo fiel cumprimento da máxima Mens sana in corpore sano, atribuída ao poeta romano Juvenal, cujo significado - "mente sã num corpo são" - remete à noção de que corpo físico e corpo espiritual são indissociáveis. Entre os esportes, além do futebol, havia ainda as competições de críquete, de hóquei - adaptado numa espécie de pelada de futebol - e o nobre lawn-tennis, esporte no qual exibiam-se os britânicos em elegantes movimentos de deixar estupefata a plateia. Além das atividades esportivas, o currículo do ginásio incluía passatempos, brincadeiras e contato com a natureza, o que, conforme avalia Anjos (1979), alinhava-se ao modelo rousseauniano, segundo o qual a educação deve ser vista como um processo natural, que privilegia as atividades inerentes à idade em que se encontram os educandos.

Não só a influência do filósofo genebrino Jean-Jacques Rousseau deve ser atribuída ao ginásio inglês, como também o fundamental aporte das propostas pedagógicas de outro suíço, Johann Heinrich Pestalozzi (1746-1827), pedagogo que, com amparo nas ideias de Rousseau, "defendeu a educação não repressiva, o ensino como meio de desenvolvimento das capacidades humanas e o cultivo do sentimento, da mente e do caráter" (ZANATTA, 2012, p. 106).

Nesse sentido, a corroborar tal filiação pedagógica, importa destacar que boa parte das práticas adotadas pelos ingleses, no ginásio, alinhava-se em grande medida ao método intuitivo, em consonância com os preceitos de Pestalozzi, quem "preconizava uma aprendizagem que deveria partir do particular para o geral, do conhecido para o desconhecido, do concreto para o abstrato" (MARCÍLIO, 2005, p. 182). Cite-se, a esse respeito, a disciplina "Trabalho Construtivo", descrita pelo narrador de Balão cativo como sendo "um ensinamento objetivo e lúdico, paralelo à Numeração, às Tabuadas, à Matemática, à Física, à Química e à Biologia" (NAVA, 1974, p. 159).

Passados os primeiros e auspiciosos meses do Anglo, deflagrava-se na Europa a $1^{\text {a }}$ Guerra Mundial. O ginásio, que ostentava um corpo docente formado privilegiadamente por professores vindos daquele continente, sofreria perdas irreparáveis em seus quadros ainda naquele ano, o que abalaria substancialmente a estabilidade da instituição.

Aos efeitos mortais da guerra, acrescente-se a contrapropaganda que sistematicamente lhe imprimiam os padres da concorrência. O ano letivo de 1915 teve início com dez matrículas 
a menos que o anterior, o que refletia os efeitos devastadores da guerra e da campanha católica sobre o ginásio, como se depreende da narrativa:

Estava dando resultados a terrível campanha que lhe moviam os padres do Arnaldo e do Claret. Os alunos escasseavam diante da propaganda feita pelos reverendos contra o nosso aprendizado sem latim, com futebol demais e oferecendo os perigos de ser ministrado por protestantes. (NAVA, 1974, p. 177)

Ao final daquele segundo ano, tomado pelo desânimo, Sadler decidiu pelo encerramento das atividades do ginásio. A breve existência do Anglo-Mineiro, entre 1914 e 1915, correspondeu justamente ao período em que lá estivera Pedro Nava como aluno interno.

Antes de se passar às representações do escritor sobre o trabalho docente desenvolvido no ginásio, é válido conhecer sua trajetória nos primeiros anos de vida, desde o nascimento, as relações familiares mais próximas, as primeiras e breves experiências escolares, até seu ingresso no internato do Anglo-Mineiro.

\section{PRIMEIROS PASSOS: DO UNIVERSO FAMILIAR AO INTERNATO}

Filho do cearense José Pedro da Silva Nava e da mineira Diva Mariana Jaguaribe, Pedro Nava nasceu em cinco de junho de 1903 na cidade de Juiz de Fora, interior de Minas, na casa de sinhá Luísa, sua avó materna, refúgio para o qual se dirigiam forçosamente as filhas da matriarca a cada fim de gravidez e período pós-parto.

Antes vivendo nas imediações da cidade, decidiu-se o jovem casal, após os primeiros meses de vida de seu primogênito, mudar-se em definitivo para Juiz de Fora, onde o pai, médico recém-formado, passaria a clinicar.

Assim, os primeiros anos de Nava na pujante cidade mineira são narrados com maestria poética e documental em Baú de ossos (1972), o primeiro volume da série de livros com os quais se inscreveu no rol dos principais nomes da literatura brasileira.

No resgate dessas imagens pueris, o narrador revisita personagens cujos afetos perpetuavam-se nas suas lembranças. Talvez a primeira delas tenha sido Rosa, uma criada de sinhá Luísa, cujas cantigas acalentavam-lhe o sono infantil. Foi Rosa quem lhe apresentou os contos maravilhosos de Perrault, Irmãos Grimm e Andersen, a cujos personagens emprestava sua voz doce e suave e, sem o saber, fazia brotar no futuro escritor sua veia imaginativa, 
despertando-lhe a vocação para a arte de contar histórias.

Da casa da avó, instalada num sobrado da rua Direita, o menino testemunhava reminiscências do passado aristocrático da família materna. E não só os velhos caixotes - onde se guardavam objetos de punição - revelavam-lhe os sombrios tempos da escravidão. Também as cenas em que presenciava o castigo físico e moral cruelmente imposto pela avó às criadas, entre as quais a própria Rosa.

De família liberal e antiescravocrata, o Dr. José Nava não compactuava com as investidas despóticas e cruéis de sinhá Luísa frente às moças negras da casa e, paulatinamente, crescia-lhe o desejo de se afastar da maliciosa proteção da sogra.

Para além dos domínios domésticos, povoam as lembranças do escritor pessoas e lugares do entorno social mais próximo, especialmente quando de suas saídas para acompanhar pai ou mãe pelas ruas da cidade. Entre suas reminiscências da época, figuram o parque vizinho, símbolo da cidade; o armazém, a farmácia, o jornal, o cinema, a barbearia, e tantos outros espaços por onde se lhe ampliava a palavra mundo.

Mais adiante, um desses espaços do mundo exterior passaria a ocupar lugar privilegiado nas lembranças de menino: o colégio Andrès, residência de família de imigrantes franceses, transformada em escola particular onde meninos e meninas, distribuídos por duas salas improvisadas, recebiam as lições do ensino primário. Nessa escola, com as irmãs Andrès, Nava teve suas primeiras experiências formais com as letras e, segundo relata, delas herdou o gosto nunca perdido pela caligrafia (NAVA, 2012).

Contudo, sua permanência no Andrès foi interrompida pela mudança da família para o Rio de Janeiro, capital federal, desejo que o pai já alimentava havia algum tempo. Instalados num sobrado da rua Aristides Lobo, no bairro do Rio Comprido, o menino passaria a experimentar, naquele ano de 1910, o convívio com outra vertente familiar, a paterna.

Os ares democráticos que se respiravam no sobrado de propriedade de tia Candoca, irmã de seu pai, bem como os hábitos eruditos e o estilo de vida intelectualizado de tios e tias que compartilhavam a residência, fizeram dessa permanência no Rio uma das etapas mais prolíficas na formação do futuro escritor, que a tudo observava. Não raro, via-se o menino envolvido nos compromissos dos familiares, servindo-lhes de companhia sempre admirada e atenta às práticas letradas destes, cujos exemplos o iniciavam no gosto pela leitura.

A esse respeito, Gabriel (2017) destaca a presença no sobrado do jornalista e poeta Antônio Salles, esposo de tia Alice, pessoas admiráveis com quem o pequeno Nava teve a oportunidade de conviver nesses tempos no Rio Comprido. A figura do tio, segundo a pesquisadora, contribuiria substancialmente para o desenvolvimento intelectual do sobrinho. A 
corroborar essa tese, Aguiar (1998) atribui à influência de Salles o estilo erudito e ao mesmo tempo chulo e caricato do escritor mineiro.

Em nova investida pelo mundo escolar, Nava foi matriculado provisoriamente numa escola pública instalada nas proximidades do sobrado, à espera de que no ano seguinte pudesse ingressar em outro colégio, mais condizente com os planos familiares para sua formação. Dessa breve experiência, contudo, não guardaria as melhores lembranças. Ao contrário, saltam-lhe à memória os atos de discriminação social, racismo e abuso de autoridade, como evidenciado nos frequentes castigos físicos e morais aplicados tiranicamente pela mestra, assim descrita pelo narrador: "Grande vaca. Toda vestida de seda negra, rotunda, espartilhada, estalando, sebenta, furibunda, olhinhos míopes verrumando os vidros do pincenê e levando a canalha a reguadas na bunda e cocorotes no quengo" (NAVA, 2012, p. 419).

A despeito dos planos familiares, o ano de 1911 traria mudanças radicais na vida de Nava: o pai adoece gravemente e morre, ao fim de um mês, deixando viúva dona Diva, em final de gravidez e com outros quatro filhos pequenos para cuidar. $\mathrm{O}$ inesperado evento precipitaria a mudança da família do Rio para Juiz de Fora, onde novamente seriam acolhidos pela avó materna em sua casa.

O período que se segue à mudança é narrado em Balão cativo (1973), segundo volume das Memórias de Pedro Nava. Essa nova temporada juiz-forana ficaria marcada por um convívio quase incômodo com a fria sinhá Luísa e a constante ausência do avô, o Major Jaguaribe:

NÃO IMPORTA MUITO A DIREÇÃO. O que sei é que aquela encosta do morro e a sombra que dele se derramava sobre a chácara da Inhá Luísa ficaram representando o lado noruega da minha infância. Nunca batido de sol. Sempre no escuro. Todo úmido, pardo e verde, pardo e escorrendo. Dele emergem as figuras próximas ou distantes com quem iríamos conviver em Juiz de Fora. Próximas, a famulagem, as crias da casa. Distantes, minha avó materna, a princesa sua filha. E um grande ausente, o Major [...] (NAVA, 1974, p. 3)

Não obstante, dos tempos adversos que se inauguraram com a saída do Rio de Janeiro, aflorava uma dona Diva forte, aguerrida e muito eficiente na arte de administrar os parcos recursos financeiros de que dispunha para prover as necessidades materiais de si e de seus cinco filhos.

Uma de suas primeiras providências nessa nova etapa foi rematricular Pedro no Colégio Andrès, no qual, por razões pouco conhecidas, o menino ficaria por curto período, até seu 
ingresso em outra instituição: o "Colégio Lucindo Filho, onde se ministrava instrução 'principalmente moral', 'sobretudo cívica' - como declamava o seu pomposo diretor" (NAVA, 1974, p. 46), Antônio Vieira de Araújo Machado Sobrinho.

Para o escritor, do Lucindo Filho ficara a imagem de um colégio desorganizado, de cujas lembranças destacam-se as "aulas desencontradas, onde aprendia noções de física e química, verbos irregulares franceses, instrução moral e cívica, história do Brasil, leitura da Seleta em prosa e verso e dos Contos pátrios" (NAVA, 1974, p. 50), onde sequer tivera aulas de geografia e aritmética e somente de forma muito vaga lhe tomavam as lições. Desse colégio, guardaria poucas lembranças relevantes, exceto pela liberdade que desenvolvera de ir e vir pelas ruas de Juiz de Fora e pelo aprendizado do vocabulário chulo de que se vira instruído pelos colegas.

Um novo fato familiar, contudo, daria fim à curta etapa escolar vivida em Juiz de Fora. Morre a avó, sinhá Luísa, em setembro de 1913, o que precipitaria a decisão do avô, Major Jaguaribe, de se estabelecer em Belo Horizonte, no que foi acompanhado por dona Diva e seus filhos. Na capital mineira, com certeza, novos rumos abrir-se-iam ao pequeno Nava, que começava a conhecer o mundo para além do universo familiar.

À custa de esforços econômicos de dona Diva e apoio material da família paterna, Pedro, então com dez anos, foi matriculado no internato do Anglo-Mineiro, ginásio recém-inaugurado em Belo Horizonte, onde teria suas primeiras experiências escolares de fato marcantes, tendo ali cursado o terceiro e o quarto ano do ensino primário.

E é justamente do período em que o futuro médico e escritor frequentou esse peculiar ginásio que se extraem os elementos para as reflexões aqui propostas, no sentido de se discutir como se desenvolvem as representações de Pedro Nava sobre os professores e que sentidos ele atribui ao trabalho docente em suas Memórias.

\section{REPRESENTAÇÕES DE NAVA SOBRE O TRABALHO DOCENTE NO ANGLO- MINEIRO}

A análise interpretativa pretendida nesta pesquisa ampara-se em estudos da História Cultural, um campo da História que, segundo Burke (2005), assistiu a uma importante renovação ao longo das décadas de 1970 e 80, momento em que passaram a se propor novos referenciais para os estudos acadêmicos, com destaque para os textos literários como objetos de estudo para a história da educação (BRITO; RIBEIRO, 2013).

Nesse contexto, Pesavento (2014) afirma que a literatura passou a ocupar um espaço privilegiado como fonte para a História Cultural em seu resgate das representações passadas, 
dado seu vínculo com uma certa sensibilidade e forma de significação do mundo que outras disciplinas não possuem.

Como aduzido por Chartier (2002), importa considerar que as representações do mundo social são determinadas pelos interesses de grupo dos quais emanam seus discursos. Para o pesquisador francês,

As percepções do social não são de forma alguma discursos neutros: produzem estratégias práticas (sociais, escolares, políticas) que tendem a impor uma autoridade à custa de outros, por elas menosprezados, a legitimar um projeto reformador ou a justificar, para os próprios indivíduos, as suas escolhas e condutas. [...] (CHARTIER, 2002, p. 17)

A partir desses pressupostos teórico-metodológicos, busca-se analisar, nesta investigação, a obra Balão cativo: memórias/2, que corresponde ao segundo volume das Memórias de Pedro Nava. Quando de sua publicação, em 1973, já circulava com grande êxito editorial o livro Baú de ossos: memórias que, publicado em 1972, inaugurara a longa série que só seria interrompida pelo suicídio do escritor, em 1984.

Vale lembrar que, ao longo de sua vida, até aquele momento, Nava era considerado um poeta bissexto no contexto cultural, embora reconhecido por sua notória contribuição para a literatura médica, materializada em inúmeros artigos e livros de referência na sua especialidade.

Após debruçar-se sobre as origens familiares no volume inicial das Memórias, bem como sobre seus primeiros anos de vida, até a morte do pai, o autor relata, em Balão cativo, os tempos vividos após o retorno da família para Juiz de Fora, momento em que o menino passa por períodos curtos entre uma e outra escola primária, até que, com a morte da avó materna, por decisão do avô, muda-se toda a família para Belo Horizonte.

Em 1914, na capital mineira, com promessas de um ensino ministrado por um corpo docente extremamente qualificado e metodologias inovadoras, inaugurava-se o Ginásio AngloMineiro. Os tempos em que lá estudou o pequeno Nava, como aluno interno, completando o terceiro e o quarto ano do ensino primário, são retratados ao longo de 67 páginas do segundo capítulo de Balão cativo, denominado "Serra do Curral", no qual o narrador relembra aspectos do convívio familiar na capital, bem como, mais detalhadamente, relata fatos do cotidiano no ginásio inglês, entre os anos de 1914 e 1915.

Logo nas primeiras páginas que dedica às memórias do ginásio, o narrador alude ao furor alcançado na comunidade local, ante as novidades trazidas pela instituição. Nos anúncios 
publicitários dos jornais da época, o novo ginásio proclamava-se moderno, tolerante e liberal, sem renunciar à adesão por estratos elevados da sociedade belo-horizontina: "A educação e a vida do Internato seguirão o sistema inglês, reconhecido como o melhor em seus efeitos sobre a formação do caráter e o desenvolvimento físico dos alunos...” (NAVA, 1974, p. 116). De forma reiterada, tais publicações exaltavam as amplas e modernas instalações do ginásio, bem como insistiam no fato de ser o seu diretor um "master of arts da Universidade de Oxford, na Inglaterra" (NAVA, 1974, p. 117), signo de prestígio que se estendia a todo o corpo docente da instituição.

Assim, no âmbito das representações sociais que passaram a se configurar com a chegada do ginásio, patenteia-se o valor atribuído a seu corpo docente altamente qualificado, como assinala Anjos (1979, p. 74):

Conforme relata o autor de Balão Cativo, o prestígio do colégio se dava não só pelo conforto de suas instalações, mas pelo fato de ser administrado por Sadler e Jones, "masters of arts" da Universidade de Oxford que, por deterem este título, também eram designados escudeiros de Sua Majestade Britânica. Investidos em autoridade numa das nações que exercia papel de dominação econômica e cultural sobre as demais, os diretores do "Anglo" adquiriam elevado "status" na sociedade brasileira e, intimamente ligados à classe dirigente, seguiam diretrizes educacionais de características aristocráticas.

A narrativa de Nava confirma tais proposições, visto que antes mesmo da abertura do ginásio já se disseminava, nos círculos sociais de Belo Horizonte, um sentimento de entusiasmo pela instituição comandada por ingleses de tamanha envergadura intelectual. É o que se depreende da fala do Dr. Lourenço Baeta Neves, engenheiro ilustre e amigo da família que, logo após matricular seus filhos no ginásio, revelara a dona Diva suas primeiras impressões sobre o Anglo: “[...] Estou voltando entusiasmado com o colégio e com o diretor. Um cavalheiro admirável. É o Doutor Sadler, master of arts oxoniano. Nada, absolutamente nada! Melhor para a mocidade que a educação que eles estão pretendendo dar [...]” (NAVA, 1974, p. 115).

Se a promessa de um ginásio moderno e de caráter renovador atraía os pais, não é de duvidar que o mesmo entusiasmo tomasse conta dos meninos que, como Pedro, passaram a alimentar a esperança de se verem livres do tradicionalismo que imperava nos colégios católicos. Note-se, a esse respeito, a indignação do garoto ao presenciar conversa entre sua mãe e D. Mariquinhas, quando esta procurava dissuadir dona Diva da ideia de matriculá-lo no Anglo:

Nada disso, Diva. Você está doida? Enfiar seus filhos no meio de metodistas? Os meus vão para o Claret e é lá que você vai pôr os seus. Eu, que estava doido pelo Anglo, quase ajoelhei para pedir a D. Mariquinhas que calasse a boca e 
afastasse de minha vida a sombra sebenta da batina dos padres que ela inculcava. (NAVA, 1974, p. 115)

Vale lembrar que D. Mariquinhas, na verdade, fizera questão que o marido, Dr. Lourenço, matriculasse seus filhos no Anglo, do que se depreende que não via com bons olhos o fato de que D. Diva, de vida mais simples e longe de ser considerada de sua casta, também ali matriculasse seus próprios filhos. Esta, por sua vez, a despeito da caríssima mensalidade de 90\$000, não deu ouvidos à pretensa amiga e, de forma resoluta, matriculou Pedro no tão desejado ginásio.

Do episódio, em suma, infere-se que os ingleses já alcançavam, naquele momento, confiança e prestígio entre os adultos de Belo Horizonte, além de grandes expectativas entre os futuros alunos, os principais interessados nas modernas instalações esportivas e nos seus métodos pouco ortodoxos que, ao menos pelo que faziam crer os anúncios, em nada se assemelhavam aos colégios concorrentes.

Em meio aos documentos de que se valia Nava para o registro desses tempos, destacamse matérias da imprensa local em que se dava publicidade às visitas de gente ilustre às dependências do ginásio. Em referência a uma dessas reportagens, o narrador descreve uma visita registrada em fotografia, na qual despontava a figura altiva do diretor, apresentando-se com seu ar elegante e fino, corpo atlético e levando, pendurada no braço, a imponente beca preta de que se despira apenas por cortesia aos visitantes (NAVA, 1974).

Junto a outros pais de alunos - entre os quais, importantes personagens da sociedade local - também D. Diva e familiares lá estiveram em visita, ocasião de deslumbramento ante a estrutura ampla e moderna dos pavilhões. Confirmava-se, in loco, o que os anúncios publicitários já desenhavam no imaginário daquela gente: no prédio da frente, de três andares, circularam pelos dormitórios dos alunos maiores e passaram pelos quartos dos professores. Conheceram secretaria, tesouraria, sala de visitas, de aulas, residência do diretor, sala de jantar, cozinha e despensa. Em outro pavilhão, tiveram acesso aos quartos dos menores, bem como aos depósitos, rouparia, vestiários, lavatórios, além de quartos de empregados e outros tantos de professores. Isso tudo se completava com magníficas instalações para a prática de esportes, destacando-se a piscina, o pavimento de ginástica e os campos de futebol. Eternizara-se, na lembrança do narrador, o maravilhamento de D. Diva com o que via e sentia: "Minha Mãe não cabia em si de contente. Vejo-a até hoje, magra, moça, toda de preto, rindo para tudo e todos, entrando comigo no escritório do Mr. Rose, para as últimas formalidades" (NAVA, 1974, p. 121). 
Na descrição dessas primeiras impressões sobre o internato, o escritor parece recuperar o vigor da juventude. O prédio novo, exalando cheiro de tinta fresca, era metáfora de uma nova etapa na sua jornada de amadurecimento:

Todo o colégio era claro e alegre, recendendo ao pinho-de-riga dos assoalhos, à tinta a óleo dos portais e à cal fresca das paredes. Nunca eu tinha morado em casa nova e aquele cheiro ficou, para sempre, em minha lembrança, associado a ideias inaugurais e juvenis. Até hoje, quando sinto a cal virgem dos prédios em construção, recupero o Anglo e aquela sombra propícia da serra do Curral da minha infância. (NAVA, 1974, p. 121)

Ficam evidentes as marcas desse caráter inaugural na reflexão que faz o narrador ao relatar seu primeiro dia de internato no ginásio. Até aquele momento, Nava só havia estudado como aluno externo. Nem sequer tivera um período suficientemente longo de permanência em cada uma das instituições anteriores. Ademais, naquelas idas e vindas entre Juiz de Fora e Rio de Janeiro, pouco contato tivera com outros meninos: "Ainda não tinha convivido, concorrido, dado de cotovelos com gente de minha idade. Ia ter essa experiência, como interno, no Anglo. Ia viver por mim mesmo, arranjaria novos amigos e começaria a ter os primeiros inimigos" (NAVA, 1974, p. 126).

Assim, no relato que passa a fazer de seus tempos de Anglo, o narrador logo revela o tom paternalista que prevaleceria nas relações entre o professorado e os alunos, o que fica patenteado desde o início das atividades, quando da chegada dos internos ao ginásio, em meio a um meticuloso ritual de recepção organizado à inglesa.

Aquilo parecia coisa ensaiada de véspera. No saguão do prédio da frente, o Mr. Sadler, de beca, recebia os meninos, pais, mães, embrulhos e malas. Imediatamente entregava o garoto a um professor que sumia com ele para as profundas do colégio, o que era um meio de despedir depressa os progenitores, acompanhantes e correspondentes. Uma turma de empregados carregava a bagagem atrás do dono. Tudo ia ter na sala de jantar onde a enfermeira dos anúncios fazia a triagem. Abria as malas que eram recolhidas ao depósito junto à cozinha, enquanto seu conteúdo ia para os escaninhos das rouparias, nos térreos dos dois prédios. Era ainda a tal enfermeira que separava os alunos em dois grupos. Os pubescentes, maiores, que eram despachados para o Mr. Cuthbert, e os infantes, menores, encaminhados ao Mr. Jones. Cada um destes conduzia seus jurisdicionados até o seu dormitório e pedia que ali ficassem esperando a hora do jantar. (NAVA, 1974, p. 125)

A propósito, Jones é, muito provavelmente, a figura mais representativa do significado que os professores do Anglo alcançaram na formação intelectual de Nava. As descrições que o narrador dedica ao vice-diretor e professor de estilo inigualável, em geral, são pautadas pelo 
reconhecimento em face das contribuições que o mestre lhe teria dado, tanto no âmbito pedagógico, como na sua inserção definitiva no mundo da literatura.

Responsável pela cátedra de Inglês, Jones exercia com autêntica maestria seu papel. Adotando uma espécie de método Berlitz, de caráter imersivo e gestual, não permitia lápis nem papel pois, segundo ele, "a coisa tinha de entrar pelos olhos, pelas orelhas e ser guardada na memória" (NAVA, 1974, p. 147). E os resultados, em geral, atestavam a eficácia de suas estratégias didáticas, como narrado neste segmento:

À custa de paciência e dessa água mole em pedra dura, ao fim de pouco os alunos bípedes estavam arranhando sua fala. [...] E guardei para sempre, dessas aulas, o gosto pelo idioma admirável e pelos desenhos e músicas que se tiram de seus verbos, seus adjetivos, seus substantivos - sobretudo de seus nomes próprios... (NAVA, 1974, p. 148)

A despeito da competência incontestável do master of arts, não raro se detém o narrador no relato de passagens muito divertidas, protagonizadas por um Jones confuso entre o inglês e o português, aos que se mesclava intrometidamente o espanhol, arrancando risos por todos os lados:

[...] nem sempre as aulas do Jones corriam calmas. Éramos tomados de risos coletivos e histéricos, unânimes, paroxísmicos, intermináveis, que punham o professor fora de si. Why are you screaming in such a panic? Se ele dissesse só em inglês, vá lá... O diabo é que ele traduzia para um português meio espanholado. Por que gritan ustedes? Porque están en tal penico? Era fatal que ele pronunciasse pânico desse jeito e aí é que todos fazíamos o coro de ruídos — o pan e o ekhos da etimologia. Rebolávamos de rir. Sufocávamos. Mas... por quê? essa hilaridade que se alastrava de repente, irreprimível como o disparo duma boiada... Era uma entonação da voz do Jones, um jeito seu de olhar, aquele meter da língua entre o lábio inferior e a dentadura, um erro de pronúncia ou de tradução, um reflexo da sua careca, talvez folha de arbusto, talvez ninguém - os meninos eram arrebatados pelo repente do chiste e o estouro dos risos começava. O Jones. (NAVA, 1974, p. 148, grifos do autor)

Hilaridades à parte, Jones teve papel fundamental na iniciação do futuro escritor pelas sendas da literatura clássica universal, não só pelo idioma britânico que lhe abria portas para a leitura dos originais ou traduções, como pela generosidade e perspicácia do mestre que, ao compreender as inclinações do menino para as letras, presenteava-lhe verdadeiras pérolas literárias, volumes que Nava guardaria para sempre na estante e nas melhores lembranças daqueles tempos. 
Exemplo disso pode-se constatar a partir de um relato alusivo às humilhações a que se submetia Pedro cada vez que vestia seus calções de futebol. $O$ uniforme improvisado, que não passava de calças velhas encurtadas, era frequentemente objeto de estridente caçoada dos colegas. Sentindo-se desconfortável com aquela zombaria, o menino buscava de todas as formas safar-se das partidas com uma e outra desculpa, até que, tendo sido desmascarado em certa ocasião pelo Jones - que àquela altura também se encarregara das atividades esportivas - não lhe restou alternativa senão vestir os famigerados calções, fato este seguido da já esperada saraivada de apupos de toda parte. O evento, contudo, fez aflorar no mestre um sentimento de empatia para com o jovem humilhado, compreendendo, por fim, a relutância deste em participar dos jogos.

Diante do episódio, demonstrando um caráter justo e benevolente, Jones não só o desobrigou das aulas de futebol, como the ofereceu de presente um exemplar do livro The Grateful Mouse Princess or Rooster, Pouletta and Cluckeglinda, traduzido para o inglês por Edith Renouf, joia que ele guardaria para sempre como recordação indelével do mestre e amigo: “Guardo até hoje, desmerecido, todo bichado, o presente de meu inimitável Mr. Jones - como lembrança do lúcido instante de comunicação que tivemos e da amizade que lhe dei ali - sem reservas e para sempre" (NAVA, 1974, p. 124). Ficam evidenciados, assim, o respeito e a gratidão que o narrador nutre pela figura do professor.

Em outro ponto da narrativa, o autor reitera a contribuição de Jones no desenvolvimento de seus hábitos de leitura:

Já contei meus dissabores com a roupa de futebol, de como o Jones me dispensara desse jogo e me despencara assim, na leitura, na contemplação e no isolamento. À hora em que todos desciam para o campo, eu ficava para trás e me sentava no meio da escada de cimento que conduzia a ele. Quando levantava a cabeça e deixava meus personagens de ficção, via, agitando-se embaixo, meus companheiros de infância. O Tempo tornou-os irreais e esbatidos, matou porção deles - mas não pôde prevalecer contra os heróis daquelas páginas - sempre na mesma e cada vez mais vivos. (NAVA, 1974, p. 142)

No mais, ressalte-se o afeto que se eternizara nas lembranças do escritor ao falar do professor que passou a admirar como amigo. Na descrição com que o representa fisicamente, a partir de uma das fotos que dele conservara, adivinha naquela imagem "dois olhos bondosos dentro da expressão sorridente, simpática e cheia de curiosidade" e remata: "[...] o nosso Jones era cheio de dignidade" (NAVA, 1974, p. 149).

De modo geral, prevalece na narrativa, um tom bem-humorado e muitas vezes burlesco na caracterização dos professores. À semelhança do que já apontava o narrador acerca do Jones, 
no caso de Hyghmes - responsável pelas atividades físicas antes de ser substituído por aquele - ficam ainda mais evidentes as dificuldades de comunicação com os alunos:

O Hyghmes colocava-se à nossa frente e encetava as extensões, torções, supinações, flexões, pronações, aduções, rotações e circunduções que devíamos imitar. Estabelecia-se a confusão porque nos primeiros dias não entendíamos patavina de inglês e a alimária era incapaz de se expressar em português. Aliás, nem no seu próprio idioma, porque os sons que ele emitia, os grunhidos que dava e os roncos, em nada lembravam a língua falada pelo Sadler, pelo Jones, pelo Carlyon, pelo Goodburn. (NAVA, 1974, p. 133)

Nas descrições físicas sobre os professores, o tom burlesco se manifesta, ainda, na técnica de caricatura que o escritor, dada sua habilidade no desenho, tão bem desenvolveu. Note-se, como exemplo, a profusão de adjetivos como "gorducho, pançudo, atarracado, ruivo" com os quais apresenta um Hyghmes desequilibrado e que "vivia fervendo de cólera" (NAVA, 1974, p. 133).

Percebe-se, contudo, que o viés caricaturesco impresso nas descrições não tem raízes em mágoas ou rancores eventualmente trazidos do passado, mas se explica, sobretudo, por suas opções estilísticas e pelo modo criativo com que o Nava escritor dá vazão ao Nava ilustrador. Comprova-o, ao menos no caso dos professores, o fato de que nem mesmo o bom amigo Jones é poupado da pena zombeteira com que o narrador o descreve:

Acentuavam logo o cômico de sua careca polida e como que esculpida no marfim rosado das bolas vermelhas dos bilhares. Mais, as maçãs salientes, o nariz arrebitado, de ponta fina, mas de vultosas ventas móveis, suscetíveis, vibráteis e farejeiras como as dum cão de caça. Havia ainda a cortina da bigodeira arriada sobre o lábio superior, tal qual a que reapareceria anos depois, exornando as fachadas dos cômicos Chester Conklin e Ben Turpin. Seus dois fabulosos cacoetes: o eclesiástico, de ficar com mãos e dedos em concha, batendo as polpas das falangetas direitas contra as esquerdas; o selvagem, de segurar a dentadura de baixo, esgueirando a língua entre ela e o lábio inferior, enquanto cerrava a boca com força - o que lhe dava uma catadura de botocudo. Fazia ora um, ora outro, às vezes os dois, conjuntamente — e era o delírio. (NAVA, 1974, p. 149)

Em contrapartida, se uma ressalva se pode fazer ao padrão jocoso observado nas caracterizações dos professores, talvez o comprove a descrição feita sobre a D. Célia Joviano, que fica incólume a qualquer menção negativa: "Ela era simpática, alegre, saudável, tinha olhos rasgados e noturnos, boca sanguínea de alvorada rindo sem parar de dentes brancos" (NAVA, 
1974, p. 156). De suas aulas, tidas como deliciosas, salientem-se ainda os elogios que o narrador dirige à professora, dela afirmando que

[...] ensinava bem e para valer. Caligrafia, português, os verbos, a gramática, rudimentos de análise. Tudo obedecendo a um programa. Dentro do ensino meio fantasista dos ingleses, o de D. Célia distinguia-se pela organização, seguimento e método. Tinha de quem sair, pois era filha de seu Artur Joviano - professor e diretor da Escola Normal. Além da estrutura da língua nossa, D. Célia fazia-nos estudar seu funcionamento em prosa e verso. Mandava-nos decorar trechos de José de Alencar, Macedo, Coelho Neto, Bilac, Alberto de Oliveira, Raimundo Correia, Augusto de Lima. Foi este que me tocou para recitativo que me deixou perplexo. (NAVA, 1974, p. 156)

O comentário sobre o método de D. Célia merece atenção especial na medida em que revela, ainda que superficialmente, uma concepção de ensino atribuída aos ingleses pelo escritor como sendo imaginativa, própria do improviso, embora o faça apenas em relação ao ensino, uma vez que, no tocante à cultura escolar, não esconde sua admiração pela competência da instituição na organização das atividades diárias. Ainda que não se aprofunde na classificação das propostas pedagógicas implementadas no âmbito das disciplinas, o que o narrador reúne sob a denominação "método inglês" parece traduzir a ideia de um conjunto de práticas inovadoras, em que sobressaía a competência e o espírito criativo de cada um dos mestres.

Outra disciplina sobre a qual se centra a narrativa é a chamada "Numeração", que era ministrada pelo Westerling. Conforme apresentada pelo narrador, constituía preâmbulo aos estudos da Aritmética, destinando-se à memorização das operações de somar, diminuir, multiplicar e dividir, por meio da tabuada cantada aos moldes de uma ópera, de cuja regência se encarregava um Westerling altivo e orgulhoso à frente do coro:

Começava por baixo, nos dois e dois, quatro, subia: sete menos quatro, três; galgava de repente às multiplicações por oito, por dez; arrasava tudo nas divisões por onze, doze, quinze e disparava nos trens-de-ferro como o sete vezes oito cinquenta e seis menos dezessete mais vinte e cinco noves fora um! Quando ninguém errava e a coisa era seguida por todos na alegria do compasso martelado pelos seus braços, o Westerling entusiasmado queria mais e desandava a gritar: outra vez! todos juntos! (NAVA, 1974, p. 153, grifo do autor)

Dentre os vários componentes curriculares do ginásio, vale destacar uma disciplina denominada "Trabalho construtivo". A matéria, ministrada pelo professor Carlyon, é referida pelo narrador como a predileta entre todas, dado seu caráter objetivo e lúdico, o que se pode inferir a partir da descrição das atividades didáticas, nas quais se revela a progressão dos 
conhecimentos partindo-se do concreto para o abstrato e uma aprendizagem pautada na percepção da realidade pelos sentidos e pela observação:

Faziam-se desenhos e módulos a eles se aplicando proporções e correlações que implicavam a ideia de números, frações simples, algarismos arábicos e romanos, do círculo, da circunferência, do raio, do diâmetro, da esfera, do cubo, do poliedro, do peso, volume, área, escala; do plano, da planta, da medida das coisas e da mensuração do homem. (NAVA, 1974, p. 159)

As estratégias didáticas implementadas pelo Carlyon nos estudos do "Trabalho construtivo", assim como pelos outros professores das "Lições de Objetos" e "Conhecimentos Gerais", são mostras do alinhamento do ginásio para com os pressupostos do pedagogo suíço Johann Heinrich Pestalozzi, especialmente no que se refere ao método intuitivo, metodologia que, segundo Marcílio (2005, p. 182), “partia da valorização da intuição como fundamento de todo conhecimento, ou seja, da compreensão de que a aquisição de conhecimentos decorria dos sentidos e da observação".

Como já apontado anteriormente, na avaliação de Anjos (1979), o currículo do AngloMineiro reproduzia ideais para a educação e para a criança preconizados por outro suíço, o filósofo iluminista Jean-Jacques Rousseau (1712-1778). Segundo ele, a educação deve ser compreendida como um processo natural, em que se deve valorizar a infância e as atividades concernentes a esse período da vida.

No Anglo, não só a ênfase na prática de esportes e o caráter lúdico do "Trabalho construtivo" pareciam alinhar-se às propostas rousseaunianas para a educação. Outra atividade que se pode destacar nesse sentido eram os constantes passeios, nos quais se colocavam os meninos em contato com a natureza, além de uma atividade ainda mais interativa, que consistia no preparo da terra, no plantio e cultivo, até a colheita de hortaliças:

O diretor inventara aquilo. Todo o fundo do colégio, dando para Maranhão e Tomé de Sousa, fora dividido em canteiros para serem tratados pelos alunos que assim o quisessem. Tive o meu. Recebi regador, tesoura, ancinho, pá, picareta, enxada-mirins - tudo parecendo de brinquedo. Aprendemos a riscar o local do canteiro, a revolver a terra dura numa profundidade de três palmos, a misturá-la com estrume, a regá-la dias e dias até que cessasse a fermentação, que o solo perdesse a acrimônia e se tornasse apto a receber o grão. Foi quando nos deram os envelopes cheios de sementes e tendo do lado de fora a figura colorida do vegetal que delas nasceria. Assim plantei minhas couves, cebolas, alfaces, tomates e rabanetes. (NAVA, 1974, p. 141) 
Já sobre as aulas de canto do Cuthbert, apresenta-se um regente indignado com os que desafinavam, destinando-lhes sua invariável ameaça: "You, there, se continuar a cantar como uma vaca, I'll break your nape!” (NAVA, 1974, p. 160). Apesar do tom ameaçador e da aparente violência nas palavras do mestre, novamente o que se extrai do relato não são os dissabores da ocasião, mas prevalece a exaltação dos seus efeitos positivos no curso do tempo e perpetuados na memória, afinal, como confessa o narrador, "cada uma destas músicas se destaca como um contorno especial nos céus do passado, céus da infância" (NAVA, 1974, p. 161).

A propósito, evidencia-se na narrativa uma certa relativização dos aspectos negativos do ginásio. Nesse sentido, Le Moing (1996), biógrafa de Nava, chega a referir-se a uma idealização do passado remoto do escritor, traduzida nas Memórias. Por seu turno, Dozol (2009) chama a atenção para os signos da gratidão, do reconhecimento e do bom-humor de que se revestem as reminiscências naveanas acerca dos tempos escolares.

A esse respeito, vale recordar que, em mais de uma oportunidade, faz-se menção a um ou outro castigo físico ou moral, coerções, ameaças; mas, em momento algum o autor chama a atenção para o caráter autoritário dessas medidas. Veja-se, como exemplo, certa passagem em que o próprio Sadler teve de intervir numa das aulas do Jones, quando este já expunha em humilhação pública um dos alunos. Diante da balbúrdia da garotada, o castigo foi inevitável, como lembra o narrador: "Copiamos mil vezes e durante um mês ficamos sem natação, sem excursões e sem sobremesa" (NAVA, 1974, p. 153).

Outras passagens, especialmente aquelas em que se flagrava um Jones desconcertado diante da explosão de risos que ele mesmo provocava com suas gafes, dão conta de punições morais das quais nem mesmo Pedro se livrara: "Eu já sabia que tinha de ficar na sala escrevendo cem, duzentas, mil vezes que eu era um menino corrupto, depravado, aborrido, falso ou nocivo [...]" (NAVA, 1974, p. 151).

Não obstante, subjaz à narrativa um tom condescendente, em que o autor se exime de comentar a validade de tais métodos; ao contrário, relega-os a segundo plano, classificando-os como de pouco rigor, especialmente se comparados às práticas recorrentes na educação brasileira:

Os bifes não eram lá muito rigorosos e havia pouco castigo. Verdade, também, que poucas infrações, porque nossa liberdade de ir e vir era muito grande e maior ainda o nosso bel-prazer. A educação brasileira é que tem a mania de proibir. Ali, à inglesa, quase tudo se podia. Só em casos excepcionais havia punição. (NAVA, 1974, p. 163)

No mais, pauta-se a narrativa pelo signo do bom-humor, da burla, da caricatura, em descrições ou relatos nos quais se adverte a predileção do autor pelo caráter pitoresco dos 
episódios e personagens. Por outro lado, em muitas situações, seja pela inaptidão comunicativa dos professores, seja pelo autoritarismo demonstrado nas punições físicas ou morais, revela-se um narrador que, intencionalmente ou não, relativiza os aspectos negativos de tais práticas.

Em síntese, pôde-se constatar a prevalência dos aspectos positivos nas representações de Nava sobre o trabalho docente no ginásio Anglo-Mineiro, na medida em que o narrador dá ênfase à competência didática e ao caráter dos professores, bem como à contribuição de parte deles para sua formação intelectual e, mais particularmente, para sua introdução no mundo das letras.

Assim, pelo que se extrai da narrativa, o prestígio alcançado pela instituição, desde sua instalação em Belo Horizonte, confunde-se com a competência de um corpo técnico muito organizado, ao qual dedica o escritor mostras incontestáveis de reconhecimento e gratidão pelo significado que teve em seu percurso formativo.

\section{CONSIDERAÇÕES FINAIS}

No âmbito da proposta lançada neste estudo, com a finalidade de discutir as representações da escola manifestadas por Pedro Nava em seu livro Balão cativo: memórias/2, volume que constitui parte de sua monumental obra literária, buscou-se analisar os sentidos atribuídos na narrativa sobre o trabalho docente, a partir das experiências acadêmicas vividas pelo escritor no internato do Ginásio Anglo-Mineiro, em Belo Horizonte, entre 1914 e 1915, onde finalizou seus estudos primários.

Os dados resultantes da análise e interpretação da narrativa revelaram a estreita relação entre a escola e a formação do sujeito, permitindo-se compreender que as representações do escritor sobre os tempos escolares são marcadamente influenciadas pelo que significou a instituição para sua formação.

Evidencia-se um estilo próprio de conceber a narrativa, na qual o escritor exerce sua veia artística transitando entre um mestre das palavras e um exímio ilustrador que, subrepticiamente colore de ironia as descrições de seus personagens. Além do caráter burlesco próprio da caricatura, prevalece o bom-humor e a predileção pela comicidade dos eventos.

Não raro se nota certa relativização dos aspectos negativos, tanto no que tange às dificuldades de comunicação dos professores - em sua maioria estrangeiros com pouca familiaridade com o português - como pela adoção de práticas repressoras, tais como ameaças 
e castigos físicos e morais. Embora mencione tais ocorrências, o narrador se furta a qualquer juízo de valor que mereça destaque nessa questão.

Por fim, ressalte-se o caráter de reconhecimento que o autor das Memórias dedica aos mestres do Anglo-Mineiro, destacando-lhes o caráter - mais particularmente em relação ao Jones, de quem se considera eternamente amigo - e, no mais das vezes, extremamente competentes em seu fazer pedagógico. Mais ainda, rende-lhes homenagem e lhes declara gratidão pelas contribuições que aportaram a seu processo formativo.

\section{REFERÊNCIAS}

AGUIAR, Joaquim Alves de. Espaços da memória: um estudo sobre Pedro Nava. São Paulo: Editora da Universidade de São Paulo: Fapesp, 1998.

ANJOS, Maria Cecília Tinoco dos. Descrição da vida escolar em romances brasileiros. 1979. 136 f. Dissertação (Mestrado em Educação) - Instituto de Estudos Avançados em Educação, Fundação Getúlio Vargas, Rio de Janeiro.

BRITO, Arlete de Jesus; RIBEIRO, Maria Augusta. História da educação e literatura: possibilidades de relações. Bolema, Rio Claro, v. 27, n. 45, p. 97-116, abr. 2013. Disponível em: http://www.scielo.br/scielo.php?script=sci_arttext\&pid=S0103-

636X2013000100006\&lng=en\&nrm=iso. Acesso em: 28 ago. 2018. DOI:

http://dx.doi.org/10.1590/S0103-636X2013000100006.

BURKE, Peter. O que é história cultural? 2. ed. Rio de Janeiro: Zahar, 2005.

CHARTIER, Roger. A história cultural: entre práticas e representações. 2. ed. Algés, Portugal: Difel - Difusão Editorial S. A., 2002.

DOZOL, Marlene de Souza. Memórias escolares: sem ressentimentos. Educação \& Realidade, Porto Alegre, v. 34, n. 2, p. 225-237, mai./ago. 2009. Disponível em: https://seer.ufrgs.br/educacaoerealidade/article/view/9353. Acesso em: 13 out. 2018.

GABRIEL, Maria Alice Ribeiro. Orlas da memória: a lembrança futura de Antônio Salles na obra de Pedro Nava. Alea, Rio de Janeiro, v. 19, n. 2, p. 307-322, maio 2017. DOI: 10.1590/1517-106x/2017192307322. Disponível em: http://www.scielo.br/scielo.php?script=sci arttext\&pid=S1517106X2017000200307\&lng=pt\&nrm=iso. Acesso em: 15 out. 2018.

LE MOING, Monique. A solidão povoada. 2. ed. Rio de Janeiro: Editora Nova Fronteira, 1996.

MARCÍLIO, Maria Luiza. História da escola em São Paulo e no Brasil. São Paulo: Imprensa Oficial do Estado de São Paulo: Instituto Fernand Braudel, 2005. 
MINAYO, Maria Cecília de Souza. O desafio da pesquisa social. In: MINAYO, Maria Cecília de Souza (Org.); DESLANDES, Suely Ferreira; GOMES, Romeu. Pesquisa social: teoria, método e criatividade. 28. ed. Petrópolis, RJ: Vozes, 2009, p. 9-29.

NAVA, Pedro. Baú de ossos: memórias. Rio de Janeiro: Companhia das Letras. 2012. (Ebook)

NAVA, Pedro. Balão cativo: memórias/2. 2 ed. Rio de Janeiro: J. Olympio, 1974.

PESAVENTO, Sandra Jatahy. História \& história cultural. 3 ed. Belo Horizonte: Autêntica Editora, 2014.

ZANATTA, Beatriz Aparecida. O legado de Pestalozzi, Herbart e Dewey para as práticas pedagógicas escolares. Teoria e Prática da Educação, v. 15, n. 1, p. 105-112, set. 2012. Disponível em: http://periodicos.uem.br/ojs/index.php/TeorPratEduc/article/view/18569. Acesso em: 27 jan. 2021. DOI: 10.4025/tpe.v15i1.18569.

\section{SOBRE OS AUTORES}

Márcio José Pereira de Camargo é doutorando em Educação na Universidade de Sorocaba (Uniso). Tem Mestrado em Educação pela Universidade de Sorocaba e Licenciatura em Letras Português-Espanhol pela mesma universidade. É membro do Grupo de Pesquisa em História da Educação no PPGE-Uniso. Professor Titular da Universidade de Sorocaba.

E-mail: marciojpcamargo@gmail.com

ORCID: https://orcid.org/0000-0001-5531-7038

Wilson Sandano é doutor em Educação pela Universidade Metodista de Piracicaba, mestre em Educação pela Universidade Metodista de Piracicaba e graduado em Pedagogia pela Universidade de Sorocaba. Atualmente é professor titular do Programa de Pós-graduação em Educação da Universidade de Sorocaba.

E-mail: wilsonsandano@uol.com.br

ORCID: https://orcid.org/0000-0001-9587-3733 